\title{
Uji Aktivitas Antibakteri Ekstrak Kasar Bawang Putih (Allium sativum) terhadap Bakteri Shigella dysenteriae yang Resisten terhadap Ampisilin
}

\author{
${ }^{1}$ Arimaswati, ${ }^{2}$ Yessy Toding Mendaun, ${ }^{2}$ Hilma Yuniar T, ${ }^{1}$ Yenti Purnamasari \\ ${ }^{1}$ Fakultas Kedokteran Universitas Halu Oleo \\ ${ }^{2}$ Program Pendidikan Dokter FK UHO \\ ${ }^{3}$ Bagian Patologi Klinik RSUD Kota Kendari \\ Email: yenti.purnamasari@ymail.com
}

\begin{abstract}
Background : Gastrointestinal infections, especially caused by Shigella dysenteriae bacteria is still a health issue in Indonesia. The number of ampicillin resistance to $S$. dysenteriae has been widely reported. Garlic (Allium sativum) is a traditional medicine that efficacy as an antibacterial. Garlic contains an organosulfur compound Allicin. Research Purpose: This study aimed to determine the antibacterial activity of garlic rule extract on the growth of $S$. dysenteriae bacteria that are resistant to ampicillin. Research Methods: This study used the experimental with post test only control group design. The antibacterial activity test was determined based on the diameter of clear zone formed. Test were performed on garlic filtrate, ciprofloxacin as a positive control and aquades as a negative control. Each treatment was performed three times. Research Result: This research showed that rule extract of garlic (A. sativum) had a clear zone against $S$. dysenteriae that was resistant to ampicillin. Conclusion: The conclusion of this research was that rule extract of garlic (A. sativum) had an antibacterial activity against $S$. dysenteriae which resistant to ampicillin.
\end{abstract}

Keywords : Antibacterial activity, Garlic (A. sativum), S. dysenteriae

\section{PENDAHULUAN}

Penyakit infeksi diperkirakan menyebabkan kematian 11 juta anak tiap tahunnya, 99\% dari kematian ini terjadi di Negara berkembang, dan 4 juta diantaranya kematian terjadi pada 1 tahun pertama kehidupan. Diare akut merupakan salah satu penyakit infeksi dan menjadi penyebab kematian kedua diseluruh dunia .(Nugroho dkk., 2014).

World Health Organization (2017) menyatakan bahwa diare merupakan salah satu penyebab utama mortalitas dan morbiditas diseluruh dunia. Diare menjadi penyebab kematian kedua pada anak dibawah usia 5 tahun, kasus diare mencapai 4 juta kasus dengan kematian anak 525.000 setiap tahunnya. Riskesdas (2007) menunjukkan prevalensi diare secara nasional adalah 9\%. Berdasarkan kelompok umur, prevalensi diare tertinggi ditemukan pada balita sebesar 16,7\%. Penyebab kematian karena diare tertinggi pada kelompok usia 29 hari - 11 bulan $(31,4 \%)$ dan usia 1-4 tahun $(25,2 \%)$. Angka prevalensi diare untuk seluruh kelompok umur di Indonesia pada tahun 2013 cenderung menurun yaitu 3,5\% dengan insiden terbanyak terjadi pada balita (Riskesdas, 2013).

Diare merupakan salah satu dari sepuluh penyakit terbanyak yang ditemukan di Sulawesi Tenggara berdasarkan Profil Kesehatan Sultra (2012) jumlah kasus diare di Provinsi Sulawesi Tenggara tahun 2011 berjumlah 96.644 kasus dengan total diare yang ditangani sebesar $60.48 \%$ dengan kejadian tertinggi terdapat di Kolaka serta diare berdarah (disentri) sebanyak 2.350 kasus. 
Diare berdarah (disentri) dapat disebabakan oleh Shigella sp. (disentri basiler), enteroinvasive Escherichia coli (EIEC) dan Amoeba (disentri amuba), penyebab yang paling sering mengakibatkan kesakitan dan kematian adalah disentri basiler (Nafianti dan Sinuhaji, 2005). Banyaknya penggunaan antibiotik tanpa disertai resep dokter menyebabkan banyaknya kejadian resistensi antibiotik. Bakteri gram negatif seperti $S$. dysentriae dapat diobati antibiotik golongan penisilin seperti tetrasiklin dan ampisilin serta kloramfenikol dan kotrimosazole (Soedarto,2007).

Namun, berdasarkan Guideline WHO (2005) tentang shigellosis keempat obat di atas tidak dapat digunakan lagi karena telah resisten terhadap bakteri $S$. dysentriae dan hal serupa dimuat dalam suatu review artikel tahun 2005 yang menyatakan kemunculan dan penyebaran dari $S$. dysentriae yang resisten terhadap antibiotik kotrimoksazole, ampisilin, tetrasiklin, dan asam nalidiksat. Obat-obat ini adalah obat yang murah dan mudah didapatkan sudah tidak dapat lagi digunakan untuk terapi empiris. Saat ini untuk penanganan diare berdarah antibiotik pilihan pertama yang dapat diberikan adalah golongan kuinolon seperti ciprofloksasin namun harga jenis ini tergolong mahal (Sari, 2015; WHO, 2005).

Bawang putih (Allium sativum) telah lama dikenal masyarakat bukan hanya sebagai bumbu masakan, namun juga memiliki khasiat sebagai obat tradisional. Bawang putih merupakan agen antibakteri kuat terhadap bakteri gram positif dan gram negatif seperti Salmonella, Streptococcus, Porphyromonas ginggivalis, Staphylococus, Klebsiella, proteus dan Shigella (Lekshmi dkk.,2015).

Dalam penelitian yang dilakukan oleh Upa (2017) menguji efek antibakteri kandungan ekstrak etanol bawang putih (A. sativum) terhadap bakteri $S$. dysentriae diperoleh hasil ekstrak etanol tidak memiliki efek antibakteri hal ini mungkin disebabkan karena kandungan alisin dalam bawang putih (A. sativum) telah hilang akibat pemanasan (Upa, 2017; Sadeghian dan Ghazvini 2002). Berdasarkan latar belakang tersebut, maka peneliti ingin melakukan penelitian untuk mengetahui efek antibakteri bawang putih (A. sativum) yang diperoleh tanpa melalui proses pemanasan, selain itu melihat banyaknya laporan angka kejadian resistensi seperti yang dilaporkan oleh WHO (2005) bahwa $S$. dysentriae telah resisten terhadap ampisilin, kloramfenikol, kotrimoksazole dan asam nalidiksat, maka peneliti juga ingin melakukan penelitian efek antibakteri bawang putih ( $A$. sativum) terhadap $S$. dysentriae yang resisten terhadap ampisilin.

\section{METODE PENELITIAN}

Penelitian ini merupakan penelitian analitik eksperimental laboratorium. Penelitian ini dilaksanakan pada bulan Desember 2017 di Laboratorium Mikrobiologi Fakultas Kedokteran UHO. Pengujian anti bakteri dilakukan dengan metode difusi cakram. Sebanyak $100 \mu \mathrm{L}$ filtrat bawang putih (A. sativum) yang dikumpulkan dengan cara menggerus daging umbi bawang putih dan disaring menggunakan kertas saring diteteskan ke atas paper disk dan dimasukkan ke dalam cawan petri berisi medium Nutrient Agar (NA) padat yang telah diisolasikan $30 \mu \mathrm{L}$ inokulum bakteri $S$. dysentriae $0.5 \mathrm{Mc}$ 
Farland kemudian diinkubasi pada suhu $37^{\circ} \mathrm{C}$ selama $1 \times 24$ jam. Bakteri uji terlebih dahulu diuji kepekaannya terhadap ampisilin dengan metode difusi cakram pada medium NA dan menunjukkan tidak ada zona bening disekitar disk ampisilin menandakan bakteri uji yaitu $S$. dysentriae resisten ampisilin (Gambar 1).

\section{HASIL}

\section{a. Persiapan sampel dan filtrasi}

Sampel pada penelitian ini yaitu umbi bawang putih yang segar, masih melekat pada bonggolnya, berjumlah 89 buah per bonggol dengan besar sama, tidak membusuk dan cacat serta beraroma khas. Umbi bawang putih dibersihkan dan ditimbang sebanyak 40 gram kemudian dihaluskan dengan menggunakan lumpang kemudian disaring untuk mendapatkan filtrat tanpa serat bawang putih. Berat bawang putih (A. sativum) halus yang telah digerus seberat 38 gr dan diperas lalu disaring dan didapatkan $2 \mathrm{~mL}$ filtrat $100 \%$.

\section{b. Identifikasi bakteri uji}

Hasil yang diperoleh yaitu tampak koloni bakteri berwarna merah (gram negatif), berbentuk batang dengan ukuran berbeda-beda (basil polimorf) seperti terlihat pada Gambar 1 .Dari sifat morfologi dan gram bakteri yang diamati sudah sesuai dengan ciri bakteri S. dysenteriae.

\section{c. Uji resistensi ampisilin}

Pengujian resistensi ampisilin dilakukan dengan metode difusi dengan menggunakan cakram antibiotik ampisilin. Cakram antibiotik diletakkan ditengah medium NA yang sebelumnya telah ditumbuhkan dengan bakteri $S$. dysenteriae. Tujuannya untuk melihat diameter zona bening yang terbentuk disekitar cakram antibiotik ampisilin .Hasil uji resistensi ampisilin dapat dilihat pada Gambar 1.

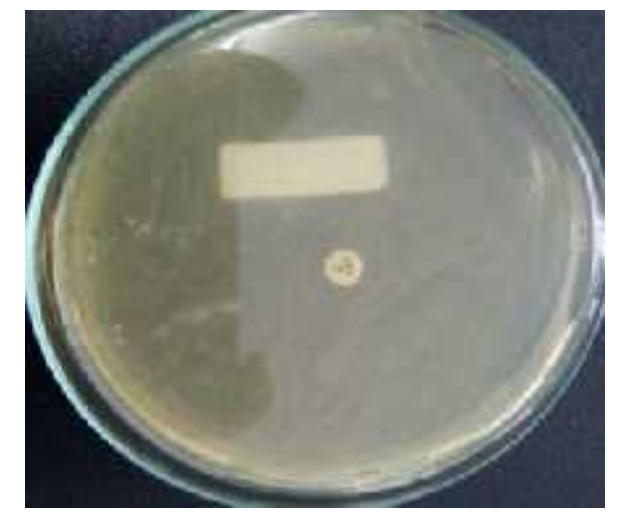

Gambar 1. Hasil uji resistensi ampisilin terhadap $S$. dysenteriae.

Pada gambar kita tidak menemukan zona bening yang terbentuk sehingga dapat kita simpulkan bahwa bakteri $S$. dysentriae yang digunakan telah mengalami resistensi.

\section{d. Uji aktivitas antibakteri filtrat bawang putih (Allium sativum)}

Uji aktivitas antibakteri bawang putih dilakukan dengan mengambil filtrat bawang putih (A. sativum) dan dengan menggunakan kertas cakram,kemudia menggunakan kontrol positif yaitu siprofloksasin dan kontrol negatif aquades kemudian diinkubasi selama 24 jam dengan suhu $37^{\circ} \mathrm{C}$ dengan tiga kali pengulangan didapatkan hasil seperti tertera pada Tabel 1.

Berdasarkan Tabel 1 kita dapat melihat bahwa dengan menggunakan filtrat murni bawang putih (A. sativum) $100 \%$ tidak terbentuk zona bening disekitar cakram. Oleh sebab itu peneliti menggunakan cara lain, dimana filtrat murni $100 \%$ dan serat bawang putih ( $A$. 
sativum) yang diperoleh sebagai residu pada saat penyaringan dimasukan kedalam cawan petri tanpa menggunakan paper disk hasilnya dapat terlihat seperti Gambar 2 .

Tabel 1. Hasil pengukuran diameter zona bening pada filtrat murni bawang putih (Allium sativum) terhadap pertumbuhan bakteri $S$. dysentriae

\begin{tabular}{lcccc}
\hline \multirow{2}{*}{$\begin{array}{l}\text { Variabel } \\
\text { bebas }\end{array}$} & \multicolumn{4}{c}{ Diameter Zona Bening (mm) } \\
\cline { 2 - 5 } & $\mathbf{X}_{\mathbf{1}}$ & $\mathbf{X}_{\mathbf{2}}$ & $\mathbf{X}_{\mathbf{3}}$ & Rata-Rata \\
\hline $\begin{array}{l}\text { Filtrat } \\
100 \%\end{array}$ & 0 & 0 & 0 & 0 \\
$\begin{array}{l}\text { Kontrol } \\
\text { Positif } \\
\text { Kontrol }\end{array}$ & 27 & 32 & 31 & 30 \\
Negatif & 0 & 0 & 0 & 0 \\
\hline
\end{tabular}

Sumber : Data Primer 2017

Keterangan :

$\mathrm{X}_{1} \quad=$ Pengulangan $\mathrm{I}$

$\mathrm{X}_{2} \quad=$ Pengulangan II

$\mathrm{X}_{3} \quad=$ Pengulangan III

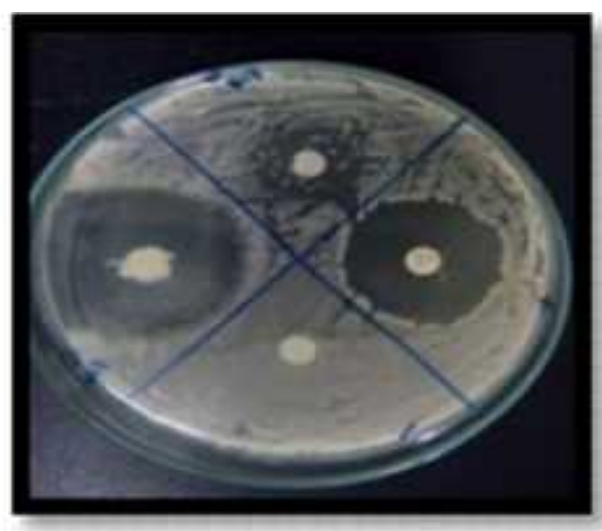

Gambar 2. Hasil uji aktivitas antibakteri filtrat dan serat bawang putih (A. sativum) terhadap pertumbuhan bakteri $S$. dysenteriae.
Tabel 2. Interpretasi hasil pengukuran ratarata diameter zona bening filtrat bawang putih (Allium sativum)terhadap pertumbuhan bakteri Shigella dysenteriae

\begin{tabular}{clcc}
\hline $\begin{array}{c}\text { No } \\
\text { V }\end{array}$ & $\begin{array}{l}\text { Variabel } \\
\text { bebas }\end{array}$ & $\begin{array}{c}\text { Diameter } \\
\text { Zona } \\
\text { Hambat } \\
\text { (mm) }\end{array}$ & Interpretasi \\
\hline 1. & $\begin{array}{l}\text { Filtrat Murni } \\
100 \%\end{array}$ & 0 & Lemah* \\
2. & $\begin{array}{l}\text { Kontrol } \\
\text { Negatif } \\
\text { kontrol } \\
\text { Positif } \\
\text { Filtrat }+ \text { Serat } \\
100 \%\end{array}$ & 0 & Lemah* \\
4. & 30 & Kuat* \\
\hline
\end{tabular}

\section{PEMBAHASAN}

Bawang putih dikenal sebagai obat yang banyak memiliki khasiat, khususnya sebagai antibiotik alami dalam melawan berbagai bakteri. Berdasarkan hasil penelitian diperoleh hasil dimana filtrat bawang putih awalnya terbentuk zona bening di ekstrak 100\% namun ditengah zona bening yang terbentuk terdapat koloni bakteri, hal ini dapat dijelaskan karena beberapa faktor.

1. Faktor pertama adalah suhu, pada beberapa penelitian, Pada suhu ruangan proses terbentuknya alisin ini berjalan 10-15 menit, enzim ini juga sangat sensitif terhadap $\mathrm{pH}$ asam (Dusica, 2011). Alinase tidak dapat bertahan pada $\mathrm{pH}$ terlalu asam sedangkan bakteri Shigella dysentriae dapat bertahan pada $\mathrm{pH}$ yang asam.

2. Faktor kedua yaitu kondensasi alisin menjadi senyawa yang memiliki aktivitas antibakteri yang lemah. Semakin tinggi suhu lingkungan akan mempercepat kondensasi alisin menjadi senyawa turunan yang lebih stabil namun aktivitas antibakteri yang lemah 
(Gorji, 2013) yakni dalam bentuk, ajoene dan vinildythine hal ini sejalan dengan penelitian yang dilakukan oleh Koch dan Lawson (1996) dalam Bourlinghaus (2014) dengan membandingkan aktivitas antibakteri alisin dengan ajoene terhadap pertumbuhan bakteri Escherichia coli dan Staphylococcus aureus didapatkan hasil bahwa kadar alisin untuk meghambat aktivitas bakteri Escherichia coli dan Staphylococcus aureus setara dengan 35 kali kadar ajoene.

3. Faktor yang terakhir adalah pertumbuhan bakteri yang maksimal dalam waktu 24 jam, sedangkan alisin tidak dapat bertahan dalam suhu inkubator $\left(37^{\circ} \mathrm{C}\right)$. Alisin hanya mampu bertahan dalam suhu di bawah $23^{\circ} \mathrm{C}$ dalam waktu 16 jam Han (1996) dalam Gebreyohannes (2013). Sehingga hal ini menjelaskan terbentuknya koloni bakteri ditengah zona bening dari filtrat murni bawang putih dapat terbentuk. Jika, kita menggunakan filtrat dan serat maka zona bening yang terbentuk lebih luas dibandingkan dengan kontrol positif (siprofloksasin) hal ini disebabkan senyawa antibakteri alisin terbentuk dari reaksi enzimatik yang terjadi jika allin dan alinase yang berada ditempat berbeda didalam sel bawang putih (A. sativum) dimana reaksi ini hanya akan terjadi jika bawang putih dihancurkan. Kandungan alisin yang dimiliki lebih besar karena di dalam seratlah terdapat allin dan alinase (Dusica, 2011) yang merupakan bahan yang diperlukan untuk terbentuknya alisin sehingga, walaupun dalam suhu $37^{\circ} \mathrm{C}$ tidak akan menghalangi proses pembentukan alisin (Gorji, 2013).

\section{SIMPULAN}

Ekstrak kasar bawang putih ( $A$. sativum) memiliki aktivitas antibakteri terhadap pertumbuhan bakteri $S$. dysenteriae.

\section{SARAN}

Bagi peneliti selanjutnya perlu memperhatikan suhu dan $\mathrm{pH}$ filtrat yang digunakan. Dianjurkan untuk melakukan penelitian KBM dan KHM dengan metode yang lain.

\section{DAFTAR PUSTAKA}

Bourlinghaus, J., Nwachukwu, I., Gruhlke, M., Slusarenko, A. 2014. Allicin: Chemistry and Biological Properties. Molecules. 19: 12591-12618.

Dinas Kesehatan Sulawesi Tenggara. 2012. Profil Kesehatan Provinsi Sulawesi Tenggara. Dinas Kesehatan Sulawesi Tenggara.

Dusica, P., Vesna, D., Ljubisa, B., Mihajlo, Z. 2011. Allicin and related compounds: biosynthesis and pharmacological activity. Phys Chem Tech. 9(1): 9-20.

Gebreyohannes, G., and Gebreyohannes, M. 2013. Medicinal values of garlic: A review . International Journal of Medicine and Medical Sciences. 5(9): 401- 408.

Gorji, A. 2014. Garlic: a review of potential therapeutic effects. Avicenna Journal of Phytomedicine. 4(1): 1-14.

Lekshmi, P., NCJ., Viveka, S. 2015. Antimikrobial Spektrum of allium Species- A review. Indian Journal of science. 
Nafianti, S., Sinuhaji, B. 2005. Resisten Trimetoprim - Sulfametoksazol terhadap Shigellosis.Sari Pediatri, 7(1).

Nugroho,.S.H., Wangi,., Loehoeri,. 2014. Buku Ajar Ilmu Penyakit Dalam Edisi VI. Jakarta: Internal Publishing.

Riset Kesehatan Dasar Nasional, 2007. Laporan Nasional.

Riset Kesehatan Dasar Nasional, 2013. Laporan Nasional.

Sadeghian, A. Ghazvini, K. 2002. Antimicrobial Activity of Garlic Extract Against Shigella .Iran $J$ Med Sci. 27(3):142-144.

Sari, M. 2015. Uji Bakteriologis Dan Resistensi Antibiotik Terhadap Bakteri Eschrichia Colli Dan ShigellaSp Pada Makanan GadoGado Di Kantin UIN Syarif Hidayatullah Jakarta. Laporan
Penelitian.Program Studi Pendidikan Dokter Universitas Islam Negeri Syarif Hdayatullah. Jakarta.

Soedarto. 2007. Sinopsis Kedokteran Tropis.Cetakan: 1. Airlangga University Press. Surabaya.

Upa, G. 2017. Uji Aktivitas Antibakteri Ekstrak Etanol Bawang Putih (Allium sativum) Terhadap Pertumbuhan Bakteri Salmonella typhi Dan Shigella dysentriae.Skripsi. Program Studi Pendidikan Dokter Universitas Halu Oleo. Kendari.

World Health Organization (WHO). 2005. Guidelines For The Control Of Shigellosis, Including Epidemics Due To Shigella Dysenteriae 1.

World Health Organization (WHO). 2017. Diarrhoeal disease. 